\title{
EDITORIAL
}

\section{DISCIPLINARIDADE E INTERDISCIPLINARIDADE EM CiênCIAS dA RELIGIÃo}

DISCIPLINARITY AND INTERDISCIPLINARITY IN RELIGIOUS STUDIES

\section{DISCIPLINARIDAD E INTERDISCIPLIARIDAD EN CIENCIAS DE LA RELIGIÓN}

O debate acerca da relação entre disciplinaridade e interdisciplinaridade no processo de consolidação e difusão da disciplina Ciência da Religião, que se apresenta majoritariamente em nosso país como Ciências da Religião, considerados à luz do debate contemporâneo, deve estar na ordem do dia. Ainda que se trate de uma compreensão recente, antes mesmo desses termos virem à tona na segunda metade do século XX, nossa disciplina, um século antes, já evidenciava que o tratamento do objeto religião demandava uma abordagem em complementação e articulação entre diversas disciplinas. Assim sendo, podemos identificar na literatura especializada sobre a disciplina em seu nascedouro, bem como na fundação das primeiras cátedras ou no perfil dos primeiros eventos e publicações periódicas, que a comunidade fundante da disciplina Religionswissenschaft, que reconhecia a premissa do que outrora seria nomeado interdisciplinaridade. $O$ inaugural desse processo foi o reconhecimento de que se tratava de uma disciplina autônoma mediando e articulando os vários saberes especializados sobre o objeto. A disciplina Ciência da Religião antecipa, no horizonte do seu surgimento, um debate contemporâneo.

Se, por um lado, a história da ciência moderna reforçava o conhecimento disciplinar, favorecendo o surgimento das especializações, contemporaneamente a interdisciplinaridade se apresenta como atitude metodológica que promove a superação das barreiras das

\footnotetext{
*Doutor em Filosofia. Mestre em Ciência da Religião. Licenciado em Filosofia. PUC Minas. Brasil. Bolsista de Produtividade em Pesquisa CNPq. ORCID: oooo-0oo1-7676-9850 E-mail: flaviosenra@pucminas.br

** Mestra em Ciências da Religião. Doutoranda em Ciências da Religião. Licenciada em Pedagogia. PUC Minas. Bolsista CAPES. ORCID: 0000-0002-1739-0688 E-mail: tatyanealmeida-10@hotmail.com
} 
disciplinas e estabelecesse uma relação entre as ciências entre si para uma melhor compreensão da realidade. Hodiernamente, como atestam as principais investigações sobre o tema, disciplinaridade e interdisciplinaridade não caminham de nenhuma maneira separadas. Os estudos de Olga Pombo, Georges Gusdorf, Hilton Japiassu e Ivani Fazenda, por citar apenas alguns dos trabalhos que têm orientado nossa pesquisa sobre o tema, oferecem contribuições para o aprofundamento do debate sobre a necessária interrelação entre os pares disciplinaridade e interdisciplinaridade. O reconhecimento de marcos conceituais, métodos e procedimentos específicos que marcam a noção de disciplinaridade se conjuga com o reconhecimento do necessário intercâmbio teórico metodológico. Ao passo em que a ciência moderna se constituiu fomentando a especialização, a ciência contemporânea promoveu a interdisciplinaridade como atitude metodológica de busca pela correlação entre os saberes. Em síntese, o que se pretende afirmar é que uma abordagem disciplinar não é razão suficiente para a recusa a uma atitude metodológica interdisciplinar. Contudo, a interdisciplinaridade tampouco anula a disciplinaridade.

A mera diversidade de abordagens não é o que caracteriza a interdisciplinaridade. A análise da repercussão do debate sobre interdisciplinaridade no campo das ciências em geral, por um lado, e a discussão sobre a constituição dos princípios teórico-metodológicos da disciplina Ciências da Religião, por outro lado, demonstra haver um certo número de imprecisões a respeito do assunto. Parece haver uma apropriação equivocada e distante do debate epistemológico, metodológico e pedagógico a respeito do assunto. Sem aprofundamento nos estudos especializados, a compreensão do senso comum sobre disciplinaridade e interdisciplinaridade permanece reduzida à supressão de qualquer especificidade, à falta de qualquer articulação interna entre os saberes correlatos, à mera presença de fragmentos de estudos diversos sobre um dado objeto. Essa má-compreensão da interdisciplinaridade não interessa ao objetivo primeiro de se constituir uma disciplina autônoma, como é o caso das Ciências da Religião. Antes, trata-se da sua negação. A quem interessa que a disciplina Ciências da Religião seja um mero consórcio inespecífico e desarticulado de saberes que pretensamente estudam o objeto religião?

Disciplinaridade é o ponto de partida, mas é também o ponto de chegada na questão da interdisciplinaridade. Certamente, não podemos aqui perpassar os sentidos construídos sobre o vocábulo disciplina ao longo da história. Porém, pode-se afirmar que por disciplina, em sentido tradicional, compreende-se o modo de delimitação ou organização do trabalho sob uma dada perspectiva. Portanto, a disciplina oferece não mais do que um ângulo particular da realidade. Por si, esse não é o problema da disciplina, senão o seu fechamento 
rígido e inflexível. Portanto, o reconhecimento de objetos complexos, como é o caso do objeto da disciplina Ciências da Religião, demanda uma atitude metodológica aberta ao horizonte das várias perspectivas de análise. Contudo, desarticuladas, as perspectivas não comunicam por si mesmas a variedade dos saberes sobre o objeto. Será a disciplina, como organizadora e delimitadora a que tornará possível uma adequada compreensão do objeto sob as variadas perspectivas.

Religião (religiões, tradições de sabedoria, espiritualidades, considerados os seus correlatos e até mesmo a sua negação) é, como objeto de nossa investigação, teóricometodológica bem definida, uma realidade complexa. Não se esgota e não se reduz a elementos sociais, históricos ou psicológicos. Ao contrário, se compreende melhor do religioso quando interdisciplinarmente, através da articulação que pode ser elaborada pela disciplina Ciência da Religião, nos dedicamos à sua análise.

Sendo assim, é importante integrar e problematizar o conhecimento em Ciências da Religião enquanto disciplina autônoma a partir de sua própria delimitação científica, para, ato contínuo, empregar interdisciplinarmente, de forma consciente, conceitos e métodos em diálogo com outras disciplinas dedicadas ao estudo da religião.

Nesse sentido, entendemos que o objeto de estudo pode ser investigado sob diversas óticas. No entanto, o ponto de partida deve se orientar pelo objetivo disciplinar das Ciências da Religião, cuja investigação parte da abordagem empírica e sistemática de fatos religiosos concretos, de perfil não normativo, mas que, ademais, é um lugar de intersecção de outras áreas que também possuem disciplinas que investigam religião. Sendo assim, a pluralidade de abordagens favorece a compreensão dinâmica do seu objeto, o que precisa ser articulado em vista de uma visão global sobre os fenômenos estudados.

Nessa perspectiva, cabe à disciplina Ciências da Religião a tarefa da articulação interna entre disciplinas da religião, porém guiada por um princípio irrenunciável, qual seja, o da produção de um saber que abarque a totalidade dos aspectos que caracterizam o seu objeto. Partimos do princípio de que disciplina é a condição de possibilidade da interdisciplinaridade, sendo esta uma atitude que se assume diante do problema do conhecimento. 